\title{
Delimitation of the Paranapanema Proterozoic block: A geophysical contribution
}

\author{
1 Instituto de Astronomia, Geofísica e Ciências Atmosféricas, USP. Rua do Matão 1226, CEP 05508-900, Brazil. Email: marta@iag.usp.br \\ 2 Instituto de Geociências, UFPr.,quintas@ufpr.br \\ 3 Instituto de Geociências, USP. Rua do Lago 562, CEP 05508-080, bbleybn@usp.br
}

This study focuses on the basement structure of the Paraná Basin in South America, based on geological and geophysical data. It is a large intracratonic basin formed from the Late Ordovician until the Cretaceous, when a sequence of continental flood basalts eruptions covered the entire basin, preceding the break-up of Western Gondwana. Isostatic modeling was applied to large gravity surveys comprising more than 12,000 gravity stations. The residual Bouguer anomaly pattern, representing the crustal contribution of the crystalline basement, as well as the sedimentary and volcanic layers of the basin, reveals similarities between the basement gravity signature and the exposed rock. The stress patterns of the Late Ordovician and Cretaceous tectonic events present a geographically coincident maximum, and the correlation between gravity highs and the main attenuation (beta factor) suggests the presence of some preexistent suture zones. The resultant mosaic of gravity blocks and the location of major faults give support to the presence of an important Proterozoic cratonic feature, here referred to as Paranapanema block.

\section{Introduction}

This work contributes to the tectonics of the southeastern part of the South American Platform. A gravity study of the Paraná intracratonic basin $\left(>1,200,000 \mathrm{~km}^{2}\right)$, confirms the presence of a cratonic lithospheric block (Mantovani \& Quintas, 1996). The boundaries of this rigid block are important for many reasons, such as for the reconstruction of Gondwana and earlier supercontinents.

The Paraná basin is the erosional remnant of a larger extent basin that covered parts of Gondwana. Beneath this basin there are some old cratonic fragments that outcrop eastward of the basin, like the Luis Alves cratonic fragment ( $>2,000 \mathrm{Ma}$; Kaul \& Cordani, 2000), at NE of the Archean Rio de La Plata craton (Figure 1). The Brasiliano belts-Apiaí/Ribeira and Tijucas/Dom Felicianoborder these older cratonic nuclei (Cordani et al., 1984).

Fyfe and Leonardos Jr., (1974) and Cordani et al. (1984) proposed the existence of a cratonic fragment in the basement of Paraná basin. Cordani et al. (1984) named this sector the Paraná block and proposed some tectonic models based on the observed regional geology. Although these authors suggested the existence of this block, its age, size and boundaries were not identified.

Some direct data from deep drilling by Petrobrás and Paulipetro indicated the continuity in the basin basement of the late-Brasiliano transcurrent megafaults and their associated deposits, as well as the

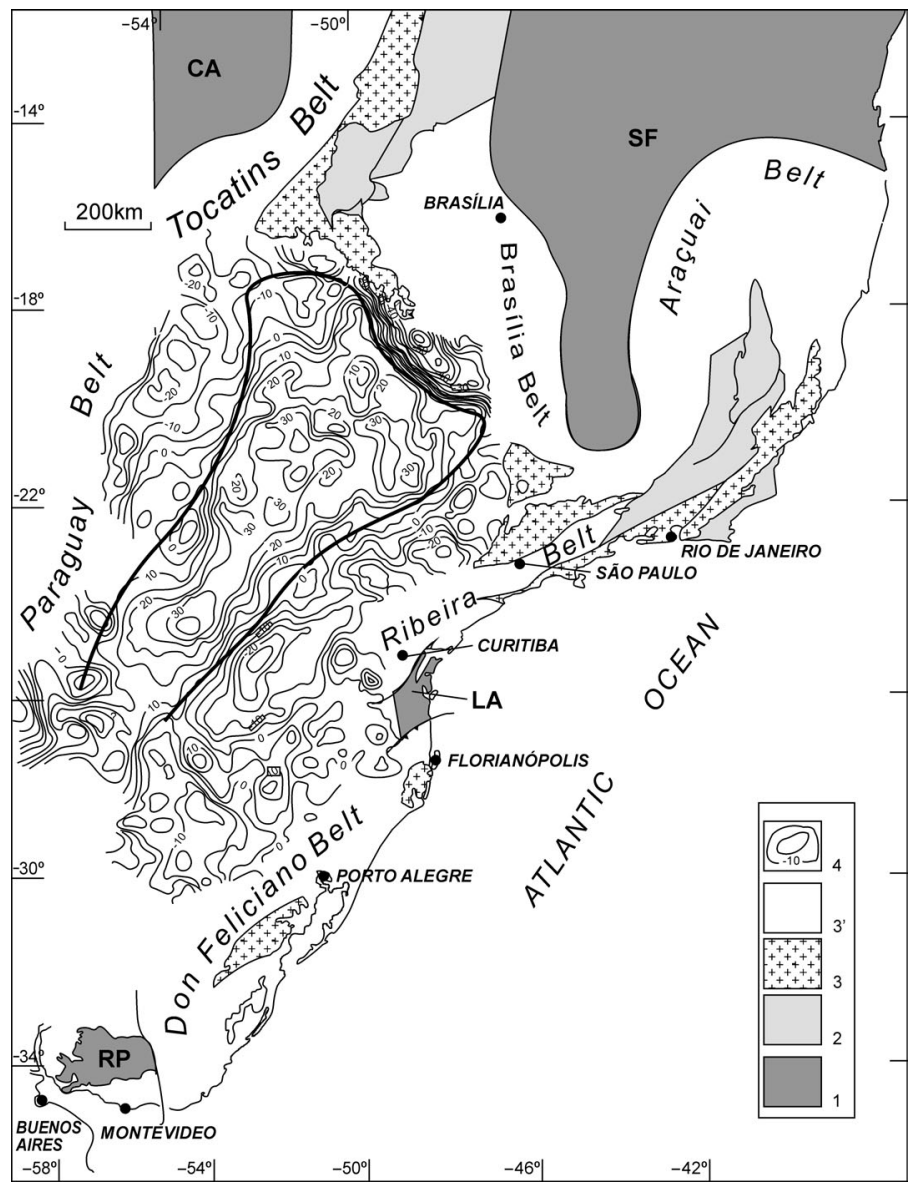

Figure 1 Tectonic segments outcropping around the basin border, in the Brasiliano framework, simplified from and based upon the scheme proposed by Campos Neto (2000).

(1) Cratonic blocks: CA-Amazonian Craton; SF-São Francisico peninsular cratonic area; LA-Luis Alves Craton; RP-Rio de La Plata Craton. Brasiliano domains - (2) Reworked Pre-Brasiliano blocks: Juiz de Fora - Embú, Central de Goiás, Valentines, Nico Perez, Cabo Frio, Punta del Leste. (3) Neoproterozoic magmatic arcs and associated realms: Mara Rosa-Goiás, Arenópolis-Socorro Guaxupé, Pelotas, Serra do Mar terrane (including Rio Negro and Rio Doce Brasiliano magmatic arcs). (3') Brasiliano Fold belts (4) Basin basement gravity contour lines.

continuity of the same sequence of foreland domains (see Figure 1 of Kaul and Cordani, 2000). The continuity beneath the basin sediments is suggested also for the Neoproterozoic belts and the Luis Alves (gneiss-granulites of Archean age and its reworked Paleoproterozoic migmatites and granulites). In addition to these data, there are remarkable sedimentary records of passive margin carbonate 
platform in the Apiaí Belt to the east, requiring the former presence (to the west) of a large continental landmass.

Finally, an active Neoproterozoic zone has been identified in northeast of the basin (Arenópolis arc and the Socorro-Guaxupé domain, Campos Neto et al., 2000; Figure 1), which collided with the São Francisco plate/craton in the Neoproterozoic (ca. $630 \mathrm{Ma}$ ).

In the westernmost part of the basin, there is additional evidence of another active continental margin, but the presence of the Pantanal cover does not allow further considerations, and this is another area demanding additional geologic and geophysical surveys.

Up to now geophysical data were not explored in order to support or refute the existence of a cratonic nucleus under the sediments of the Paraná basin. Since gravity patterns can provide the site of the boundaries between two different blocks, as well as a gravimetric signature, which is characteristic for each structure, a quite comprehensive gravity survey is analyzed here. Furthermore, the records of deep boreholes drilled all over the basin provide physical properties of the volcanic and sedimentary layers, as constraints for the geophysical considerations presented here.

\section{Regional tectonics}

The Brasiliano cycle was developed between about 890 to ca. 480 Ma in a diachronic way, until the final completion of the basement framework of the South American platform. The amalgamation of Gondwana was achieved only during the Eo-Ordovician, although some final post-tectonic volcano-sedimentary basins were formed earlier. According to Unrug (1996), it involves a mosaic of lithospheric fragments linked by several (accretionary, collisional) Neoproterozoic mobile belts.

After consolidation, the Gondwana supercontinent accumulated Paleozoic and Mesozoic sediments. Concomitantly, it was continuously laterally accreted (to the western border) by means of successive orogenic belts, in the Lower Paleozoic (Famatinian/Caledonian) and in the Permian-Triassic (Hercynian/Variscan), until the formation of Pangea (Cordani et al., 2000, 2003b).

The main cratonic fragments descending from the ancestors of the Pangea, present in South America, were reworked like the Amazonic, São Francisco (part of the Congo-Kasai-Angola) and Rio de La Plata (Almeida et al, 2000). Besides these large blocks, there are many smaller ancient crustal blocks that are gradually identified and have played different tectonic roles during later orogenies (Figure 2), (Kroëner and Cordani, 2003).

The Paleozoic sedimentary (Gondwanan) sequences cover, unrestrictedly, the major cratonic blocks and smaller blocks, the "massifs" and other basement inliers, as well as the Neoproterozoic branching system of orogenic belts located among them, i.e. the Brasiliano and Pan-African accretionary and collisional zones (Cordani et al., 2000).

\section{Geophysics}

The presence of thick sedimentary sequences over the Paraná basin enables one to identify two extensional events and the dynamics of the evolution of the basin to be studied. These tectonic events, in the Late Ordovician and in the Carboniferous, were followed by subsidence and widespread sedimentation. Subsequently, a third tectonic event took place in the Early Cretaceous that resulted in the extensive continental flood basalts magmatism ("LIP of Serra Geral"), which preceded the Gondwana break-up (Milani, 1992).

Using thermo-tectonic models, it is possible to determine the distribution of stresses that caused extensional events and the consequent evolution of the basin. Tectonic subsidence curves of the basement beneath the basin are generally obtained from these models, using lithologic data from all sedimentary piles sampled by deep wells.

The extensional event is measured by the $\beta$ (beta) factor, which is the ratio between the lithosphere thickness pre- and post-extension.

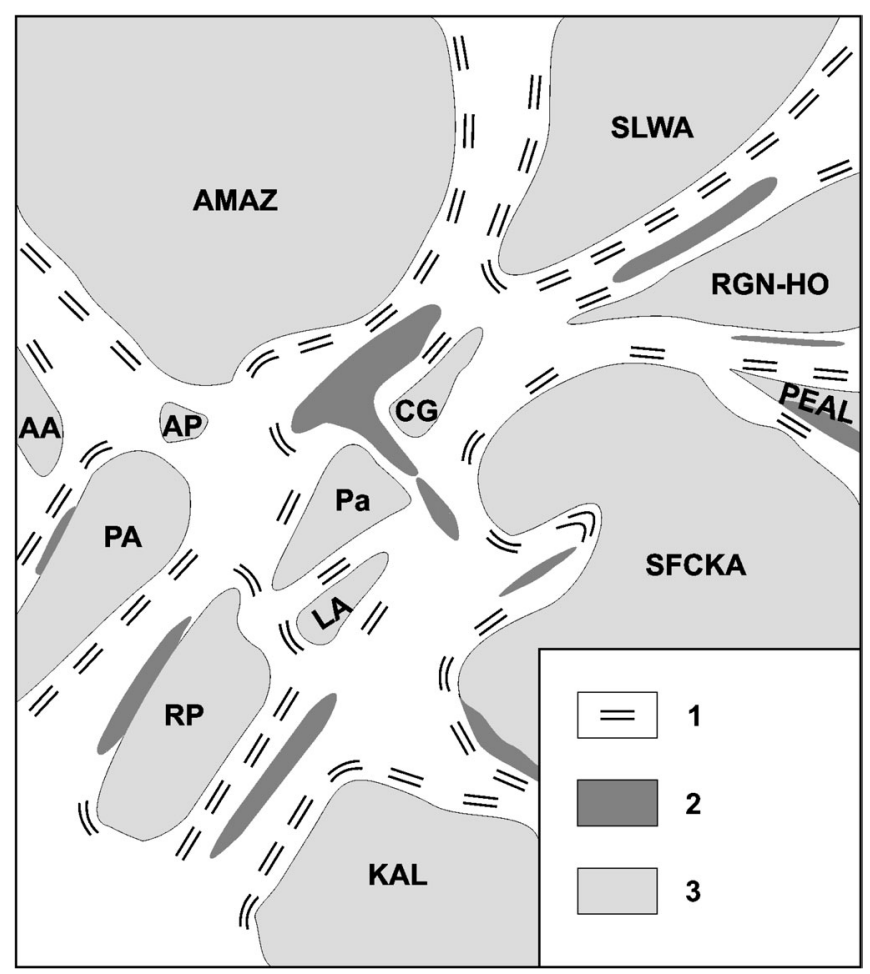

Figure 2 Schematic display of the main cratonic blocks of Western Gondwana- descendants of Rodinia- and the framework of fold belts and magmatic arcs generated among them during the Brasiliano-Pan-African collage.

Amaz. = Amazonian; SLWA = São Luis-West Africa $;$ RGN-HO= Rio Grande do Norte - Hoggar ; PEAL = Pernambuco-Alagoas; SFCKA = S. Francisco-Congo-Kasai-Angola $;$ KAL = Kalahari $;$ $C G=$ Central Goiás-Tocantins ; Pa = Paranapanema $\boldsymbol{L A}=$ Luis Alves-Curitiba; $R P$ = Rio de La Plata; Ap = Rio Apa; PA = Pampia; $A A=$ Arequipa - Antofalla - (1) Fold belts; (2) Magmatic arcs; (3) Rodinia's descendants (after Cordani et al., 2003).

The calculation of the subsidence for the basement was based upon the Royden \& Keen (1980) model, considering the spatial distribution of deformation of the crust to be different from that of the mantle lithosphere. The methodology used was based on a comparison of the subsidence theoretical curves calculated for each lithostratigraphic unit with the curves of lithology records for the boreholes (Quintas et al., 1999). The theoretical curves are based upon the Steckler \& Watts (1978) equation, which considers the porosity and compaction of the sediments with depth, being the effect of sedimentary loading a function of the densities of water, sediments and mantle, and of the thickness of the sediments. More sophisticated and precise methods have been developed (eg. Newman \& White, 1997), but information of past and present rheology is too sparse.

In order to calculate the thickness of the sediments during the history of the basin, back-stripping was used. This approach allows the determination of the depth of the basement of the basin just after stretching (Sclater \& Christie, 1980). The back-stripping analysis used data from 81 deep wells randomly distributed through the basin. The porosity function and the compaction constant, as well as the equation to determine the depth of the basement, are those of Sclater \& Christie (1980). The thermo-mechanical model considers the present isostatic equilibrium of the Paraná basin (Quintas et al., 1999).

The gravity data presented were acquired from a multi-institutional survey, including over 12,000 gravity stations throughout the basin and its borderlands, to correlate gravity and topography anomalies caused by subsurface loadings (e.g. Mantovani et al., 2003; Vidotti et al., 1999).

The Bouguer anomalies were related to the Geodetic Reference System of 1967 , and the value of $2,670 \mathrm{~kg} / \mathrm{m}^{3}$ was employed for the 


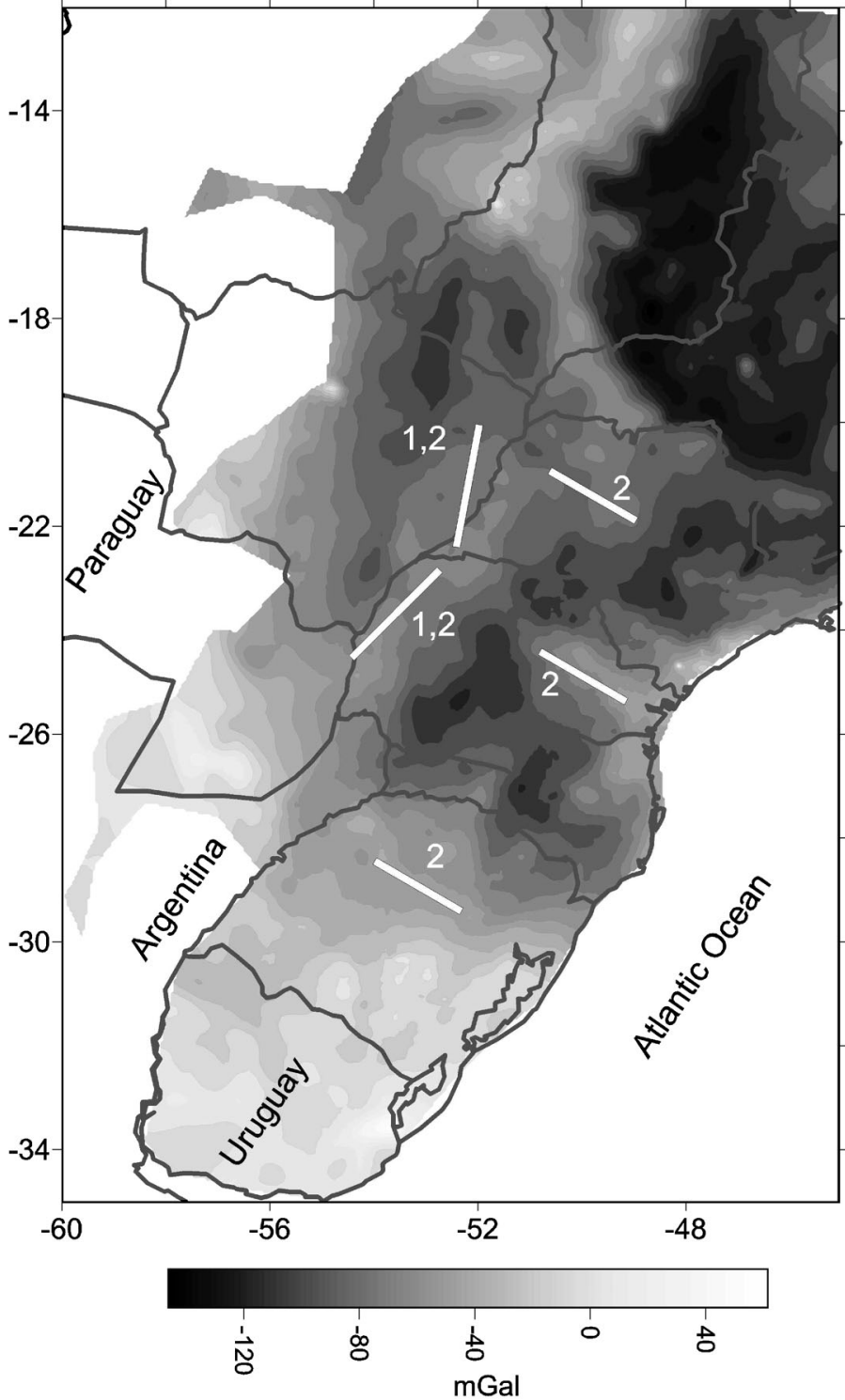

Figure 3 Map of the residual Bouguer gravity anomaly. The applied interpolation method was minimum curvature. White stripes are the principal shortening direction for the first (1) and second (2) tectonic events in the history of the basin (Quintas et al., 1999). The parameters used in the modeling are: Densities: water $=1030 \mathrm{~kg} / \mathrm{m}^{3}$, crust $=2080 \mathrm{~kg} / \mathrm{m}^{3}$, mantle $=3300 \mathrm{~kg} / \mathrm{m}^{3}$, mean lithosphere $=2800 \mathrm{~kg} / \mathrm{m}^{3} ;$ Thermal conductivities: water $=0.567$ $\mathrm{W} / \mathrm{m} \cdot \mathrm{K}$, mean lithosphere $=3.11 \mathrm{~W} / \mathrm{m} \cdot \mathrm{K} ;$ Temperature at the base of the lithosphere $=1623 \mathrm{~K}$; Thermal diffusivity of the lithosphere $=8.0 \times 10^{-7} \mathrm{~m}^{2} / \mathrm{s}$; Thicknesses: crust $=45 \mathrm{~km}$, mantle $=150 \mathrm{~km} ;$ for modeling the second event the eroded part in correspondence to the Ponta Grossa Arc was included (after Quintas et al., 1999).

upper crust density. No terrain correction was applied in the area, given the wide regional character of the survey (Figure 3). The residual Bouguer anomaly was obtained after performing a trend surface analysis (Davis, 1986). The best fit was obtained for a second degree polynomial trend surface and then subtracted from the total Bouguer anomaly to calculate the residual anomaly.

The residual field corresponds to the crustal contribution of the anomalous gravity field, which represents the crystalline basement as well as the sedimentary and volcanic layers that fill the basin. The isostatic modeling enables to observe the similarity between the gravity signature of the basement and the adjacent terranes (Mantovani \& Quintas, 1996).

\section{Reactivation of Pre-Brasiliano structures during the evolution of the Paraná Basin}

Considering the tectonic thinning for both extensional events ( $\beta$ values) and the volume of the sedimentary sequences produced along the time elapsed since the first tectonic event (back-stripping results), the calculated mean subsidence for the whole basin throughout its life (Upper Ordovician to the Upper Cretaceous) is 13.6 $\mathrm{m} / \mathrm{Ma}$ (Mantovani and Quintas, 1996). Considering that erosion is generally $10 \%$ of the observed stratigraphic column (Steckler and Watts, 1978) and taking into account the observed regional unconformities in the stratigraphic column (Milani, 1992), the existence of erosional periods must be added $(\sim 3.3 \mathrm{~m} / \mathrm{Ma})$ if this process is to be taken into consideration. This will increase the total rate of effective subsidence of the basin to $16.9 \mathrm{~m} / \mathrm{Ma}$, corresponding to the effective mean subsidence rate of the basin.

The effective mean subsidence rate represents the answer to, at least, the two major events of extensional tectonics (Late Ordovician and Carboniferous). In addition to the tectonic component of the lithosphere thinning, it includes the load of the sediments deposited in the resulting depression and the load of approximately $10^{15}$ tons (Peate et al., 1988) of the extruded volcanics as a consequence of the thermal event that preceded the continental rupture. The subsidence curves (age vs. depth) were obtained from the back-stripping method performed for each available deep well (Quintas et al., 1999).

For each tectonic event, Royden and Keen (1980) thermalmechanical analyses were applied in order to obtain the stretching factor for each event and at each point (Quintas et al., 1999). For the first two tectonic events, the main stress directions (NE-SW) follow those of the main pre-Brasiliano faults, suggesting a reactivation during the formation and evolution of the basin. Taking into account the eroded portion (Gallagher et al., 1994) in correspondence to the Ponta Grossa Arch (APG; at approximately $25^{\circ} \mathrm{S}, 50^{\circ} \mathrm{W}$ ), and the basic parameters for the best fit to the model, a pseudo-NW-SE component is also observed for the second event. The $\beta$ maxima for both tectonic events are shown in Figure 3.

The secondary component, observed for the younger tectonic event could be interpreted as an incipient manifestation of early pulses of magmatism at 140-135 Ma, whose chemical composition would be compatible with that of the APG dykes (Peate et al., 1988). Also, its pseudo-NW-SE direction could be associated with the structures developed near the Atlantic coast and related to the Gondwana break-up. These structures were associated by Turner et al. (1994) with the rotation of the southernmost part of the South American plate, forming aulacogenic structures in the Salado and Colorado basins and in the structural arcs of Ponta Grossa and Rio Grande.

For this south-southeast portion of the continent, the main direction of the stresses (SW-NE) suggests that the continental rupture has occurred taking partial advantage of the main pre-Brasiliano structures observed either in the tectonic units that crop out beyond the limits of the basin or in the structure of its internal framework.

\section{Definition of the Paranapanema Block}

The shape of each sedimentary formation and basalt layers of Paraná basin is given by Milani et al. (1994) as isopach maps. For the elaboration of each map data from deep boreholes and seismic refraction were taken into account. The gravity signature of the basin basement was obtained after subtracting the gravity component due to basin infill (sediments and basalts) from the residual Bouguer anomaly field. The calculation of the extracted gravity component took into account density differences between sedimentary formations and different volcanic rocks (Mantovani and Quintas, 1996), the values of which were obtained from core samples and outcrops of the flow sequences at $\mathrm{SE}$ of the basin where the main occurrences of felsic volcanic rocks are exposed (Peate et al., 1988). 


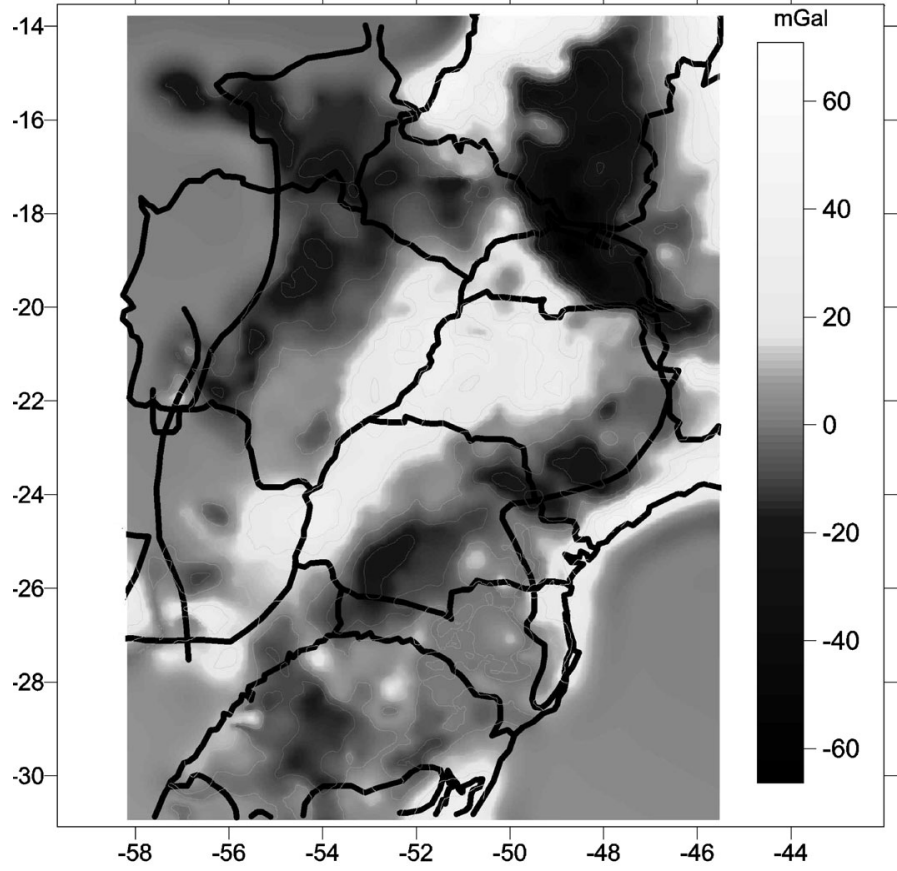

Figure 4 Geophysical interpretation of the tectonic features of the basin. In the central part, we notice the Paranapanema block (light grey), limited by gravity gradients (darker grey) that separate this block from collisional structures described in the text (after Mantovani \& Quintas, 1996).

The high gravity (Figure 4) of the basin has an almost triangular shape, bordered by steep gravity gradients, suggesting the existence of a crustal/lithospheric block present when the Brasiliano structures were formed, circumscribing such main central area/plateau. This feature was named Paranapanema block (Mantovani and Quintas, 1996).

The Paranapanema block is surrounded by different structures. To the west-northwest, the Paraguay Belt has gravity characteristics of an island arc, probably formed by the consumption of oceanic lithosphere between the Rio Apa massif and the Paranapanema block. The outcropping basement defining the gravity structure includes plutonic rocks that may represent the southern continuation of the magmatic arc of Western Goias (Pimentel and Fuck, 1992) as a result of successive soft-collisional events coalesced along the Brasiliano cycle.

To the north-northeast, a steeper gravity gradient reveals the southern part of the Brasilia belt, and the continuation of the Arenópolis magmatic arc, from south of Goiás Velho to SocorroGuaxupé (São Paulo and Minas Gerais). To the east and southeast of the main plateau, the continuation of the Apiaí and São Roque belts (Ribeira) is marked by a sequence of negative anomalies.

Based on the geophysical data and geological observations, it is possible to formally propose the presence of a cratonic nucleus during the Neoproterozoic, whose borders are zones of plate interactions (thickened continental crust). The western and northern orogenic systems were preceded by a type B accretionary process (Pimentel and Fuck, 1992), which was reactivated during the basin forming tectonics throughout the previously indicated extensional events. Incidentally, during the second tectonic event (Carboniferous), the superposition of a thermal component occurred, which predominated over the third event, with the formation of the continental flood basalt province preceding the main continental rift and the separation of South America and Africa.

\section{Conclusions}

The gravity signature of the Paraná basin basement allows the identification of the boundaries of a cratonic block, here referred to as Paranapanema, which interacted with the adjacent fold belts during the Brasiliano Cycle.

The Paranapanema block was tectonically formed probably between about 1000 and $850 \mathrm{Ma}$. The lithostratigraphic records of its evolution are mainly in its eastern portion, along the Apiaí fold belt, where a carbonate platform of shallow marine and continental margin are very common. In other peripheral areas, the continental margins sequences are neither clear nor well preserved.

The southeastern margin of the Apiaí fold belt includes the magmatic arcs of Cunhaporanga and Três Corregos (ca. $615 \mathrm{Ma}$ ), which resulted from a B-subduction between the Paranapanema cratonic fragment and the Luis Alves craton. In the northeastern area, the southern branch of the Tocantins province was formed, which includes the Arenópolis arch and the Socorro Guaxupé magmatic arch. There is evidence that in that area the subduction was oriented towards the south (the Paranapanema block had then acted as the overriding plate), due to its collision with the São Francisco and Central Goiás (underriding plates) (Van Decar et al., 1995).

The western margin shows a linear sequence of local negative gravity anomalies $(<-30 \mathrm{mGal})$ suggesting the protracting of the Paraguay fold belt, a result of consumption of oceanic lithosphere bounding the pre-Brasiliano Rio Apa block.

Field observations (Basei et al., 1999) showed that there was no physical connection between the Paranapanema block and the Rio de La Plata block to the south. The observed juxtaposition of these two blocks is controlled by a set of transcurrent faults, for which the extent of displacement is not known.

Figure 1 comprises the isopachs of our gravity study and was modified and adapted from Campos Neto (2000). It provides a good idea of the dimensions (ca. $400,000 \mathrm{~km}^{2}$ ) of the Paranapanema block and, in addition, enables the regional geological and tectonic features to be observed.

The original size, its role during the Brasiliano cycle, and collisional belts of the Paranapanema block (Pa in Figure 2) are still open to question. Additional studies of this block are still needed in order to understand the margins and development of Western Gondwana. Nevertheless, the geophysical confirmation of its existence and its delimitation no longer allows its omission in the reconstruction of Gondwanaland.

\section{Acknowledgements}

We acknowledge Professor Umberto Cordani for his urging of the study of this subject; Dr. C. Ebinger, Dr. Geismman and Prof. U. Cordani for their constructive comments and corrections that greatly improved the original manuscript; MSc. André Rugenski, for his technical and graphic/ illustration support. The financial support for the different stages of the work was provided by the National Council for Research Development $(\mathrm{CNPq})$, the São Paulo State Foundation for Research Support (FAPESP) and the National Coordination of Graduate Studies (CAPES). The Brazilian institutions responsible for the gravity database, herein used, include: the Instituto de Astronomia Geofísica e Ciências Atmosféricas da Universidade de São Paulo (IAG/USP), the Instituto Brasileiro de Geografia e Estatística (IBGE), the Observatório Nacional (ON), the Companhia de Pesquisa de Recursos Minerais (CPRM) and the Universidade Federal do Paraná (UFPR). 


\section{References}

Almeida, F.F.M. de, Brito Neves, B.B. and Carneiro, C.D.R., 2000, The origin and evolution of the South American Platform. Earth-Science Reviews, v. 50, pp. 77111.

Basei, M.A.S., Siga Jr, O., Cordani, U.G., Sato, K. and Lima, P.S., 1999, The magmatism of the Itajai Basin SC Southern Brazil and its importance to define the Proterozoic limit. In: Actas II SSAGI, 1999, pp. 287-290.

Campos Neto, M. da C., 2000, Orogenic Systems from Southwestern Gondwanan - an approach to Brasiliano-Pan African cycle and orogenic collage in southeastern Brazil. In : U.G. Cordani, E.J. Milani, A. Thomaz Filho, D.A. Campos, Tectonic Evolution of South America, Rio de Janeiro, 31th International Geological Congress, pp. 335-365.

Cordani, U.G., Sato, K., Teixeira, W., Tassinari, C.C.G., and Basei, M.A.S., 2000, Crustal Evolution of the South American Platform. In: Cordani, U.G., Milani, E.J., Thomaz Fo., A.A., Campos, D.A., Tectonic Evolution of South America, 31st International Geological Congress, Rio de Janeiro, pp. 19-40.

Cordani, U.G., Neves, B.B. de B., D'Agrella, M.S. and Trindade, R.I.F., 2003, (a). Tearing up Rodinia: the Neoproterozoic paleogeography of South American cratonic fragments. Terra Nova. v.15, no.5, pp.343-349.

Cordani, U.G., Brito Neves, B.B. de B., Fuck, R.A., Thomaz Filho, A. and Cunha, F. M. B., 1984, Estudo preliminar de integração do Pré-Cambriano com os eventos tectãnicos da Bacias Sedimentares Brasileiras. Revista Ciência-Técnica-Petróleo. Secção Exploração de Petróleo. Petrobrás/Cenpes/Sintep, Publição n. 15, pp. 70.

Cordani, U.G., Brito Neves, B.B. de B. and D'Agrella Fo., M. S, 2003, (b). From Rodinia to Gondwana: a review of the available evidence from South America. Gondwana Research, v. 6, no. 2,pp. 275-283.

Davis, J.C., 1986, Statistics and data analysis in Geology. John Wiley \& Sons, NY, 2nd ed., $646 \mathrm{pp}$.

Fyfe, W.S. and Leonardos Jr. O.H., 1974, Ancient meamorphic-migamite belts of the Brazilian Atlantic Coast: the African connection. Revista Bras. Geociências, v. 4, no. 2, pp. 247-252.

Gallagher, K., Hawkesworth, CJ. and Mantovani, M.S.M., 1994, The denudation history of the onshore continental margin of SE Brazil inferred from apatite fission track data. J. Geophys. Res., v. 99, no. B9, pp.18.117-18.145.

Kaul, P.F.T. and Cordani, U.G., 2000, Geochemistry of the Serra do Mar granitoid magmatism and tectonic implications, Southern Brazil. Rev. Bras. Geoc., v. 30, no.1, pp. 15-119.

Kroëner, A. and Cordani, U.G., 2003, African, southern Indian and South American cratons were not part of the Rodinia super continent: evidence from field relationships and geochronology. Tectonophysics,. v.375, pp.325-352.

Mantovani, M.S.M. and Quintas, M.C.L., 1996, A contribution to the study of the Paraná basin evolution. 30th International Geological Congress (IUGS), Beijing, China, Abstracts v.3, pp.102.

Mantovani, M.S.M., Vasconcellos, A.C.B.C. and Shukowsky, W, 1989, Brusque Transect-From Atlantic coast to Bolivian border, Southern Brazil. Inter-Union Commission on the Lithosphere \& American Geophysical Union, Special Publication, GGT4, (USA); (ISBN 0-87590-781-4), 22pp and 2 maps.

Mantovani, M.S.M., Brito Neves, B.B. de, Quintas, M.C.L. and Shukowsky, W., 2003, Geophysical definition of Paranapanema Proterozoic Block and its importance for the Rodinia to Gondwana evolutionary theories. European Geophysical Society, Nice, France (6-11 April), Geophysical Research Abstracts, v. 5, pp. 08053.

McKenzie, D.P., 1978, Some remarks on the development of sedimentary basins. Earth Planet. Sci Lett., v. 40, pp. 25-32.

Milani, E. J. 1992, Intraplate tectonics and the evolution of the Paraná Basin, SE Brazil. In: Inversion tectonics of the Cape Fold belt, Karoo and Cretaceous basins of Southern Africa, Wit and Ransome, Eds. Bakelma, Rotterdam, pp. 101-108

Milani,E.J., França A.B., Schneider, R.L., 1994. Bacia do Paran·. PETROBRÁS, Rio de Janeiro, Boletim de Geociências, Vol.8 n.1,pp 69-82.

Newman, R. and White, N., 1997, Rheology of continental lithosphere inferred from sedimentary basins. Nature, v. 385, pp. 621-624.

Pimentel, M.M. and Fuck,R. A, 1992, Neoproterozoic crustal accretion in central Brazil. Geology, v. 20, pp. 375-379.

Peate,D.W.; Mantovani, M.S.M. and Hawkesworth, C.J., 1988, Geochemical stratigraphy of the Parana CFB: Borehole Evidence. Rev. Bras. Geoc. v. 18, no.2, pp. 212-221.

Quintas, M.C.L., Mantovani, M.S.M. and Zalán, P.V., 1999, Uma contribuiãão para o estudo da evoluãão mecanica da Bacia do Paraná. Revista Brasileira de Geociências v. 29 , no. 3 . pp. 217-226.

Royden, L. and Keen, C.E., 1980, Rifting process and thermal evolution of the continental margin of Eastern Canada determined from subsidence curves. Earth Planet. Sci. Letters, v. 51, pp. 342-361.

Sclater, J.C. and Christie, P.A.F., 1980, Continental stretching: an explanation of the post mid cretaceous subsidence of the central-north sea basin. J. Geophys. Res., v. 85, no. B7, pp. 3711-3739.

Steckler, M.S. and Watts, A .B., 1978, Subsidence of the Atlantic-type continental margin off New York. Earth Planet. Sci. Letters, v. 41, pp. 1-13.
Turner, S., Regelous, M., Kelley, S., Hawkesworth, C.J. and Mantovani, M.S.M., 1994, Magmatism and continental break-up in the South Atlantic: high precision ${ }^{40} \mathrm{Ar}-{ }^{39} \mathrm{Ar}$ geochronology. Earth Planet. Sci. Letters, v. 1221, pp. 333-348.

Unrug, R., 1996, The Assembly of Gondwanaland, Episodes, v. 19, pp. 11-20.

Van Decar, J.C., James, D.E. and Assumpção, M., 1995, Seismic evidence for a fossil mantle plume beneath South America and implications for plate driving forces. Nature, v. 378, pp. 25-31.

Marta Silvia Maria Mantovani got her doctorate in Physics at the Campinas State University, SP in 1971. She is Professor at the Dept. of Geophysics, São Paulo University (USP) since 1990 and member of the Brazilian Academy of Sciences since 1997. Her main interest is devoted to the genesis of Continental Flood Basalts (Paraná basin) and the tectonics of S-SE Brazilian lithosphere segment. Acted as Head of Department of Geophysics (1990-1994); Chairman of National Committees of the International Lithosphere Project (1994-2000); Deputy-Director of the Institute of Astronomy and Geophysics (1997-2001); and is Director of the Science and Technology Park (2002-present) at the University of São Paulo.

Wladimir Shukowsky got his doctorate in Geophysics at the University of São Paulo. His research interests include regional gravity and magnetics applied to structural and tectonic crustal modeling, and tidal gravity variations applied to lithosphere rigidity analysis.

Benjamim Bley de Brito Neves got his doctorate at the University of São Paulo (USP) in 1975. During the last 37 years, he worked on general tectonic history of Brazil, and specially on geology of the Borborema Province, including geological mapping, hydrogeology, tectonics, and isotope geology. Since 1984 he has worked at São Paulo University, where he is Full Professor. Since 1996 he is a member of the Brazilian Academy of Sciences.
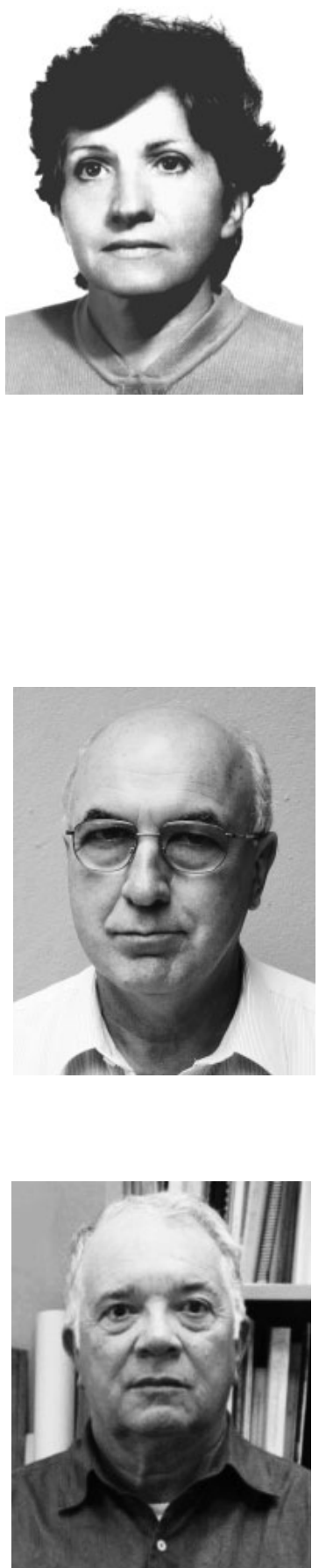

Marcia Cristina Lopes Quintas, Cartographic Engeneer, got her doctorate in Geophisics at the Institute of Astronomy and Geophysics, São Paulo University and a Post Doctorate at the University of Toronto, Canada. Presently she teaches at the Federal University of Paraná. 